CARPATHIAN JOURNAL OF FOOD SCIENCE AND TECHNOLOGY

journal home page:http://chimie-biologie.ubm.ro/carpathian_journal/index.html

\title{
EFFECTS OF SOAKING AND GERMINATION TIME ON THE ENGINEERING PROPERTIES OF FINGER MILLET (ELEUSINE CORACANA)
}

\author{
Ashwani Kumar ${ }^{1,2, \bowtie}$, Amarjeet Kaur'1, Vikas Kumar ${ }^{2}$ and Yogesh Gat ${ }^{2}$ \\ ${ }^{1}$ Deptt of Food Science and Technology, Punjab Agricultural University, Ludhiana, India -141004 \\ ${ }^{I}$ Department of Food Technology and Nutrition, Lovely professional University, Phagwara, India-144411 \\ $\triangle_{\text {ashwanichandel480@gmail.com }}$ \\ https://doi.org/10.34302/crpjfst/2020.12.1.6 \\ Article history: \\ Received: \\ 23 June 2019 \\ Accepted: \\ 10 January 2020 \\ Keywords: \\ Finger millet; \\ Germination; \\ Malting; \\ Engineering properties.

\begin{abstract}
The effect of germination time on malting loss and engineering properties namely: 1000 kernel weight, bulk density, true density, porosity, length, width, thickness, geometric mean diameter, arithmetic mean diameter, sphericity, surface area, sample volume and angle of repose were studied. Increase in germination time increased malting loss up to $35.27 \%$ after 96 hours of germination. Reduction in thousand kernel weight, bulk density and true density was $35.8 \%, 25.4 \%$ and $20.18 \%$, respectively after 96 hours of germination. Porosity of grains was decreased while length increased with increase in germination time up to 72 hours of germination. Width and thickness showed an increase up to 36 hours and 24 hour of germination, respectively, followed by a linear decrease. A similar trend was observed in geometric and arithmetic mean diameter, sphericity, surface area and sample volume of grains. Angle of repose increased from $24.93^{\circ}$ to $32.81^{\circ}$ after 72 hours of germination followed by a linear
\end{abstract} \\ decrease.
}

\section{Introduction}

Agriculture is facing various problems like deepening of water bed level and expansion in drylands (CGIAR, 2017). The changing climate conditions along with nutrient deficient soils are not favourable for cultivation of wheat and rice and worldwide agriculturists are searching for a suitable alternative to these cereals. In view of these constraints, millets have attracted the attention of agriculturists and food technologists, as these are rich in nutrients, can grow on soils with low fertility, require less irrigation and are resistant to insects and pests (Singh and Srivastava, 2006; Devi et al., 2014). Owing to this, the year 2018 was declared as the International year of millets. In this connection, finger millet, one of the highly produced millet in India with excellent nutrient quality, projects a tremendous scope in designing foods for developed as well as developing world. It possesses good drought tolerance, has ability to tolerate salinity and can be grown in soils with $\mathrm{pH}$ range of 5.0 to 8.2 (Upadhyaya, 2011). Finger millet is most nutritious among the major cereal grains. It is rich in high quality protein (Admassu et al., 2009) which contains all the essential amino acids (Mbithi-Mwikya et al., 2000). The content of free sugars has been reported in the range of 0.47 to $1.5 \%$ (Nirmala et al., 2000; Kumar, 2013) which along with high dietary fibre (12\%) (Saleh et al., 2013) make it a low glycemic food. It is also gluten free (Admassu et al., 2009; Singh and Raghuvanshi, 2012; Devi et al., 2014).The cholesterol lowering and cancer reducing studies of finger millet has also been reported (Burton and Froston, 1966; 
Burton et al., 1972). Owing to its health benefits worldwide researches are being conducted to develop value added health products from finger millet (Verma and Patel, 2013; Shukla and Srivastva, 2014). However, the high amount of phytates, phenols, tannins and enzymes in finger millet inhibits maximum absorption of its nutrients which decreases its food value. Many processing methods like soaking, germination, roasting, and fermentation have been recommended by various researchers to reduce the anti-nutrients of finger millet (Tatala et al., 2007; Venkateswaran and Vijyalakshmi, 2010). Germination is believed to be the most promising methods to reduce anti-nutrients and change the functionality and digestibility of grains (Pawar et al., 2007; Onyango et al., 2013). The germinated grains can be dried to a safer moisture limit and can be stored for further processing.

Effects of soaking and germination on the chemical composition of finger millet has been studied by many researchers (Nirmala et al., 2000; Tatala et al., 2007; Venkateswaran and Vijyalakshmi, 2010) but the effect of germination time on the engineering properties of finger millet is still unexplored. Gravimetric properties like bulk density, true density and porosity is important to determine the drying rate and aeration properties as these properties affect the rate of air flow (Sobukola et al., 2013). Knowledge of the dimensional properties like length, width, thickness, geometric mean diameter and arithmetic mean diameter are important in separation of undesirable materials like unwanted roots and shoots from malted grains. Surface and frictional properties like sphericity and angle of repose plays an important role in designing material handling equipments like hoppers, conveyor belts and storage structures like silos (Balasubramanian and Vishwanathan, 2010). Therefore, the present study was designed to study the effect of germination time on engineering properties of finger millet This information can help food researchers and processors to exploit the usage of malted finger millet grains in development of value added products.

\section{Materials and methods}

\subsection{Procurement of raw material}

Finger millet (Eleusine corcana) grains of variety VL Manduaa-315 were procured from Vivekananda Parvatiya Krishi Anusandhanshala Almora U.P. The grains were cleaned by winnowing to separate residual particles (husks, chaff and un-matured seeds). Cleaned grains were then collected, dried in a tray drier (Narang Scientific Works Limited) to the final moisture content of $8 \pm 0.5 \%$, and stored for further use. The moisture content of the samples was determined by oven drying method at $130{ }^{\circ} \mathrm{C}$ for 2 hours (AOAC, 2010).

\subsection{Malting}

Malting is a three step process consisting of soaking, germination and drying. In the present study clean grains were soaked overnight in potable water, excess water was removed, and were spread in thin layer in a seed germinator maintained at $25 \pm 2{ }^{\circ} \mathrm{C}$ and $95 \%$ relative humidity. Germination was carried for a time interval ranging from 12 hours to 96 hours. After every 12 hours interval samples were removed, dried in a hot air oven $\left(50 \pm 2{ }^{\circ} \mathrm{C}\right)$ to moisture content of $8 \pm 0.5 \%$, de-vegetated and were stored for further analysis.

\subsubsection{Malting loss}

Malting loss is defined as the weight of grain lost during the malting process (Nirmala et al., 2000). Malting loss was calculated by using the following formula

Total malting loss $(\%)=$ Weight of grains before malting - Weight of grains after malting $\times 100$ / Weight of grains before malting (Eq.1)

\subsection{Gravimetric properties}

\subsubsection{Thousand kernels weight}

Thousand kernels weight was measured by selecting 1000 grains randomly from precleaned grains. The selected kernels were weighed on a digital electronic balance. The test was performed five times and the mean value was calculated (Mariotti et al., 2006). 


\subsubsection{Bulk density}

Bulk density was measured using calibrated measuring cylinder of $1000 \mathrm{ml}$ capacity. The cylinder was filled to appropriate height with the clean grains (Mariotti et al., 2006). Bulk density was calculated by taking ratio of the sample weight and volume of the cylinder and was represented as $\mathrm{Kg} / \mathrm{m}^{3}$. Average of 5 replications was taken.

Bulk density $=$ Sample weight/volume

\subsubsection{True density}

The true density was determined by the liquid displacement method. 10 grams of cleaned grains were immersed in a $50 \mathrm{ml}$ measuring cylinder containing $20 \mathrm{ml}$ of toulene. The amount of oil displacement was recorded and true density was calculated using the formula:

True density $=$ Weight of grains/volume of displaced toluene

\subsubsection{Porosity}

Porosity is the measure of fraction in the bulk grain which is not occupied by the grain (Ramashia et al., 2017). It is calculated by putting the values of true density and bulk density in the under given formula.

Porosity $(\mathcal{E})=[(\mathrm{Pt}-\mathrm{Pb}) / \mathrm{Pt}]^{*} 100($ Eq. 2$)$

Where, $\mathrm{Pt}=$ True density, $\mathrm{Pb}$ - Bulk density

\subsection{Dimensional properties}

The principal dimensions of length, width and thickness were measured with the help of a projector with a $10 \mathrm{X}$ scale by selecting 10 random grains for each treatment, drawing images on a white paper, measuring dimensions and finally reducing them to original size by dividing with 10 . Further geometric mean diameter, arithmetic mean diameter, sphericity, surface area, and sample volume were calculated by using formulas given by various researchers (Sharma et al., 1985; Sreenarayanan et al., 1985; Jain and Bal, 1997; Ledbetter and Sisterson, 2010; Onyango et al., 2013; Ramashia et al., 2017).

Geometric mean diameter $=(\mathrm{LWT})^{1 / 3}(\mathrm{Eq} .3)$

Arithmetic mean diameter $=(\mathrm{L}+\mathrm{W}+\mathrm{T})^{1 / 3}($ Eq.4)

Sphericity $=\left[(\mathrm{LWT})^{1 / 3 / \mathrm{L}}\right] 100(\mathrm{Eq} .5)$

Surface area $=\left(\pi \mathrm{BL}^{2}\right) /(2 \mathrm{~L}-\mathrm{B})($ Eq.6)

Sample volume $=\left(\pi \mathrm{B}^{2} \mathrm{~L}^{2}\right) /[6(2 \mathrm{~L}-\mathrm{B})]($ Eq.7)
Where, L= Length, W= Width, $\mathrm{T}=$ Thickness, $\mathrm{B}=(\mathrm{WT})^{0.5}(\mathrm{Eq} .8)$

\subsection{Angle of repose}

The angle of repose was determined on a plywood surface with the help of a cylinder opened at both the ends i.e. top and bottom end. The cylinder was kept on the plywood surface and was filled up to top with cleaned finger millet grains. The cylinder was then lifted up gradually from the surface until a conical heap was formed. Angle of repose was calculated from the height and base radius of the heap formed (Owolarafe et al., 2007).

$$
\text { Angle of repose }(\theta)=\tan ^{-1} 2 \mathrm{~h} / \mathrm{d} \text { (Eq.9) }
$$

\section{Results and discussion}

\subsection{Malting loss and gravimetric properties}

Malting loss has been defined as the loss of grain mass during germination. The effect of germination time on the malting loss and gravimetric properties has been shown in Table 1.

With increase in germination time malting loss increased gradually from 0 to $35.27 \%$ after 96 hours of germination which might be due to the hydrolysis of stored complex carbohydrates into simple sugars (Handa et al., 2017) and the utilization of these sugars in the embryonic growth (Vidal-Valverde et al., 2002). Similar results have been reported by other researchers. Kumar (2013) reported a malting loss of $30 \%$ in local finger millet variety of Himachal Pradesh while Nirmala et al., (2000) reported a malting loss of $32 \%$ in Indaf-15 variety. Malting loss had a direct significant $(\mathrm{P} \leq 0.05)$ relation with gravimetric properties (fig. 1) and an increase in malting loss resulted in decreased values for thousand kernel weight, bulk density and true density and same has been observed in correlation analysis of data (Table 4). Density is the measure of the mass per unit volume and is important to design the storage structures and handling equipments. Density is dependent on surface properties like surface area and sample volume and an increase in these parameters resulted in decrease in density. Porosity was reduced significantly $(\mathrm{P} \leq 0.05)$ in the initial 72 hours of 
germination which might have been due to the migration of nutrients to surface and filling of pores during soaking. The reason for increase in porosity after 72 hours of germination might be due to the shrinking of grains and formation of cracks on the skin. A decrease in porosity has been also reported by Kumar and Prasad, on parboiling of rice (Kumar and Prasad, 2013). Porosity and density also affect the rate of moisture removal during drying (Bai et al., 2012). The grains with low porosity have a greater resistance to the removal of moisture and hence require high power aeration fans.

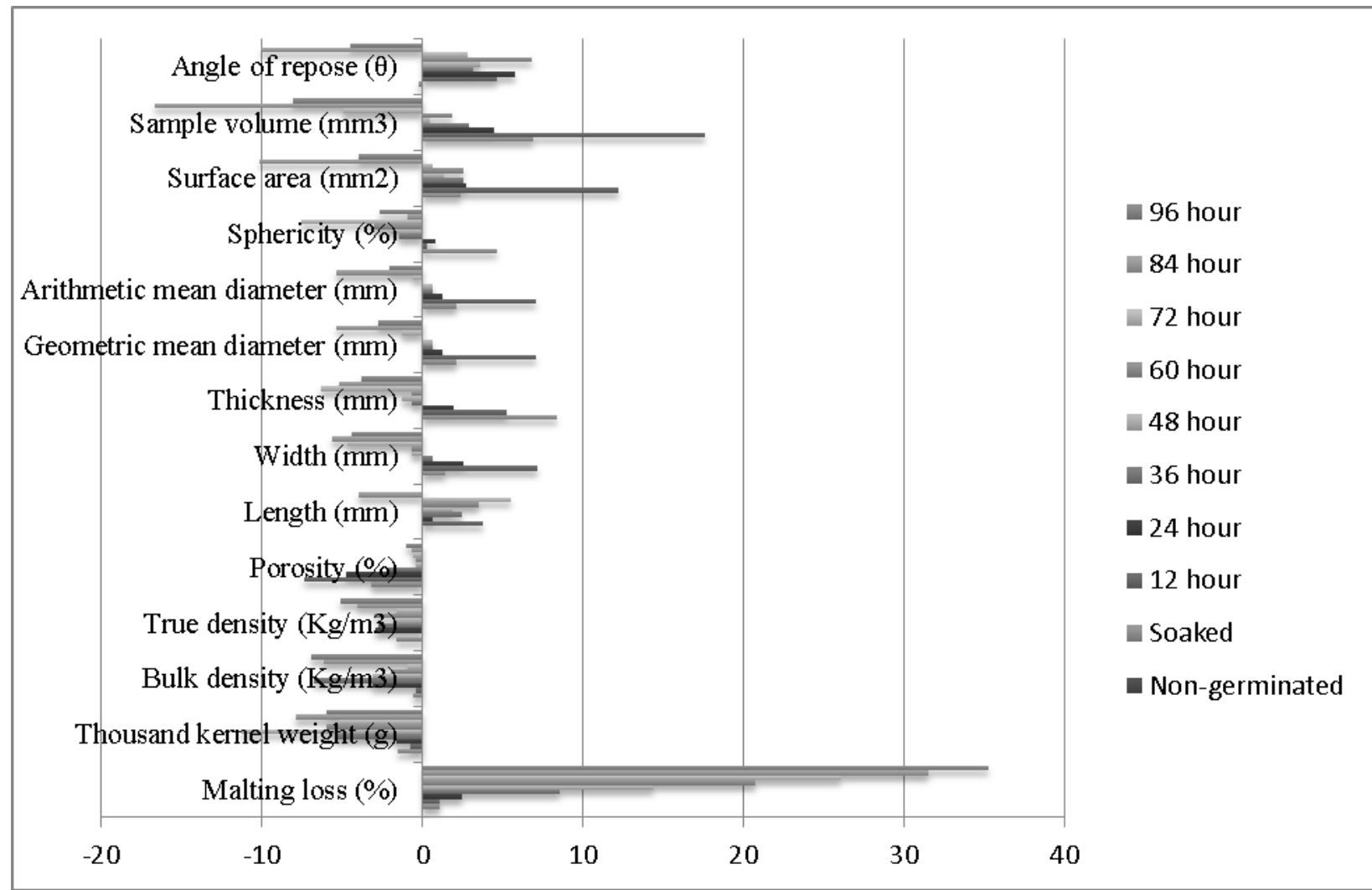

Figure 1. Effect of germination time on the malting loss and engineering properties in comparison to non-germinated finger millet grains (values for non-germinated parameters are taken as zero

Table 1. Effect of germination on malting loss and density related properties

\begin{tabular}{|c|c|c|c|c|c|}
\hline $\begin{array}{c}\text { Germination } \\
\text { Time }\end{array}$ & $\begin{array}{c}\text { Malting Loss } \\
(\mathbf{\%})\end{array}$ & $\begin{array}{c}\text { Thousand Kernel } \\
\text { Weight }(\mathbf{g})\end{array}$ & $\begin{array}{c}\text { Bulk } \\
\text { Density } \\
\left(\mathbf{K g} / \mathbf{m}^{\mathbf{3}}\right)\end{array}$ & $\begin{array}{c}\text { True Density } \\
\left(\mathbf{K g} / \mathbf{m}^{\mathbf{3}}\right)\end{array}$ & $\begin{array}{c}\text { Porosity } \\
(\%)\end{array}$ \\
\hline $\begin{array}{c}\text { Non- } \\
\text { germinated }\end{array}$ & $0.00^{\mathrm{i}}$ & $2.60 \pm 0.02^{\mathrm{a}}$ & $741.04 \pm 1.66^{\mathrm{a}}$ & $1250.00 \pm 1.1 .5^{\mathrm{a}}$ & $36.61 \pm 0.26^{\mathrm{a}}$ \\
\hline Soaked & $1.03 \pm 0.21^{\mathrm{h}}$ & $2.56 \pm 0.02^{\mathrm{b}}$ & $736.66 \pm 0.56^{\mathrm{b}}$ & $1230.33 \pm 1.76^{\mathrm{b}}$ & $35.47 \pm 0.18^{\mathrm{b}}$ \\
\hline 12 hour & $1.10 \pm 0.10^{\mathrm{h}}$ & $2.54 \pm 0.03^{\mathrm{b}}$ & $733.41 \pm 0.54^{\mathrm{c}}$ & $1229.00 \pm 0.58^{\mathrm{b}}$ & $33.03 \pm 0.11^{\mathrm{c}}$ \\
\hline 24 hour & $2.49 \pm 0.09^{\mathrm{g}}$ & $2.50 \pm 0.03^{\mathrm{c}}$ & $711.20 \pm 1.08^{\mathrm{d}}$ & $1194.33 \pm 2.60^{\mathrm{c}}$ & $31.54 \pm 0.37^{\mathrm{d}}$ \\
\hline 36 hour & $8.52 \pm 0.45^{\mathrm{f}}$ & $2.37 \pm 0.02^{\mathrm{d}}$ & $666.10 \pm 0.66^{\mathrm{e}}$ & $1162.03 \pm 2.30^{\mathrm{d}}$ & $30.86 \pm 0.59^{\mathrm{d}}$ \\
\hline 48 hour & $14.37 \pm 0.51^{\mathrm{e}}$ & $2.13 \pm 0.03^{\mathrm{e}}$ & $645.75 \pm 1.55^{\mathrm{f}}$ & $1142.73 \pm 1.76^{\mathrm{e}}$ & $30.74 \pm 0.28^{\mathrm{e}}$ \\
\hline 60 hour & $20.71 \pm 0.65^{\mathrm{d}}$ & $2.01 \pm 0.03^{\mathrm{f}}$ & $633.3 \pm 1.00^{\mathrm{g}}$ & $1109.33 \pm 2.33^{\mathrm{f}}$ & $30.70 \pm 0.19^{\mathrm{e}}$ \\
\hline
\end{tabular}




\begin{tabular}{|c|c|c|r|r|r|}
\hline 72 hour & $26.03 \pm 0.40^{\mathrm{c}}$ & $1.91 \pm 0.02^{\mathrm{g}}$ & $627.65 \pm 0.94^{\mathrm{h}}$ & $1091.73 \pm 0.88^{\mathrm{g}}$ & $29.93 \pm 0.04^{\mathrm{f}}$ \\
\hline 84 hour & $31.53 \pm 0.15^{\mathrm{b}}$ & $1.77 \pm 0.01^{\mathrm{h}}$ & $591.23 \pm 1.95^{\mathrm{i}}$ & $1049.03 \pm 1.00^{\mathrm{h}}$ & $30.92 \pm 0.07^{\mathrm{e}}$ \\
\hline 96 hour & $35.27 \pm 0.40^{\mathrm{a}}$ & $1.67 \pm 0.02^{\mathrm{i}}$ & $552.72 \pm 1.66^{\mathrm{i}}$ & $997.67 \pm 2.60^{\mathrm{i}}$ & $31.49 \pm 0.4^{\mathrm{d}}$ \\
\hline
\end{tabular}

*Values are means \pm SD of 5 replications. Different superscripts in a column indicate that they are significantly $(\mathrm{P} \leq 0.05)$ different to each other determined by Duncan's tests

Table 2. Effect of germination time on the dimensional properties of finger millet grains

\begin{tabular}{|c|c|c|c|c|c|}
\hline $\begin{array}{c}\text { Germination } \\
\text { Time }\end{array}$ & Length $(\mathbf{m m})$ & Width $(\mathbf{m m})$ & $\begin{array}{c}\text { Thickness } \\
(\mathbf{m m})\end{array}$ & $\begin{array}{c}\text { Geometric } \\
\text { Mean } \\
\text { Diameter } \\
(\mathbf{m m})\end{array}$ & $\begin{array}{c}\text { Arithmetic } \\
\text { Mean } \\
\text { Diameter } \\
(\mathbf{m m})\end{array}$ \\
\hline $\begin{array}{c}\text { Non- } \\
\text { germinated }\end{array}$ & $1.52 \pm 0.03^{\mathrm{d}}$ & $1.40 \pm 0.06^{\mathrm{bc}}$ & $1.32 \pm 0.04^{\mathrm{cd}}$ & $1.41 \pm 0.04^{\mathrm{c}}$ & $1.41 \pm 0.04^{\mathrm{d}}$ \\
\hline $\begin{array}{c}\text { Soaked } \\
12 \text { hour }\end{array}$ & $1.52 \pm 0.07^{\mathrm{d}}$ & $1.42 \pm 0.09^{\mathrm{bc}}$ & $1.44 \pm 0.13^{\mathrm{abc}}$ & $1.44 \pm 0.11^{\mathrm{bc}}$ & $1.44 \pm 0.11^{\mathrm{cd}}$ \\
\hline 24 hour & $1.59 \pm 0.05^{\mathrm{cd}}$ & $1.57 \pm 0.04^{\mathrm{a}}$ & $1.55 \pm 0.04^{\mathrm{a}}$ & $1.57 \pm 0.04^{\mathrm{a}}$ & $1.57 \pm 0.04^{\mathrm{ab}}$ \\
\hline 36 hour & $1.63 \pm 0.03^{\mathrm{c}}$ & $1.58 \pm 0.05^{\mathrm{a}}$ & $1.54 \pm 0.05^{\mathrm{ab}}$ & $1.58 \pm 0.04^{\mathrm{a}}$ & $1.58 \pm 0.04^{\mathrm{a}}$ \\
\hline 48 hour & $1.66 \pm 0.07^{\mathrm{bc}}$ & $1.57 \pm 0.05^{\mathrm{a}}$ & $1.52 \pm 0.05^{\mathrm{ab}}$ & $1.59 \pm 0.06^{\mathrm{a}}$ & $1.59 \pm 0.06^{\mathrm{a}}$ \\
\hline 60 hour & $1.72 \pm 0.03^{\mathrm{b}}$ & $1.56 \pm 0.10^{\mathrm{a}}$ & $1.51 \pm 0.12^{\mathrm{ab}}$ & $1.59 \pm 0.08^{\mathrm{a}}$ & $1.59 \pm 0.08^{\mathrm{a}}$ \\
\hline 72 hour & $1.82 \pm 0.01^{\mathrm{a}}$ & $1.49 \pm 0.01^{\mathrm{ab}}$ & $1.42 \pm 0.01^{\mathrm{bc}}$ & $1.57 \pm 0.01^{\mathrm{a}}$ & $1.58 \pm 0.01^{\mathrm{a}}$ \\
\hline 84 hour & $1.75 \pm 0.01^{\mathrm{ab}}$ & $1.41 \pm 0.01^{\mathrm{bc}}$ & $1.35 \pm 0.02^{\mathrm{cd}}$ & $1.49 \pm 0.01^{\mathrm{abc}}$ & $1.50 \pm 0.01^{\mathrm{abcd}}$ \\
\hline 96 hour & $1.75 \pm 0.01^{\mathrm{ab}}$ & $1.35 \pm 0.01^{\mathrm{c}}$ & $1.30 \pm 0.01^{\mathrm{d}}$ & $1.45 \pm 0.01^{\mathrm{bc}}$ & $1.47 \pm 0.01^{\mathrm{bcd}}$ \\
\hline
\end{tabular}

*Values are means \pm SD of 5 replications. Different superscripts in a column indicate that they are significantly $(\mathrm{P} \leq 0.05)$ different to each other determined by Duncan's tests.

\subsection{Dimensional properties}

Grain dimensions like length, width, thickness, geometric mean diameter, arithmetic mean diameter are important in designing the sieves for separation of grains from undesirable materials. For the utilization of malted grains to develop value added products, it is important to remove vegetative growth and separate the sound grains from waste material. Maximum value for length (1.82) was obtained after 72 hours of germination while the value for width and thickness was highest at 36 hours and 24 hours of germination, respectively. The increase in dimensional properties like length, width and thickness of finger millet grains might have been due to the swelling of starch granules during soaking as water migrates to grains during soaking and leads to irreversible swelling (Mir and Bosco, 2013). One of the more reasons behind increase in length might be the adherence of dried epicotyl and hypocotyl to grain after drying as their complete removal is not possible. A prolonged germination resulted in decrease in dimensional properties which might have been due to the formation of pits and holes on the surface of germinated starch granules and formation of small size particles due to the breakdown of larger particles (Li et al., 2017). A similar trend was observed in the geometric mean diameter and arithmetic mean diameter (Table 2).The diameter is dependent on length, width and thickness of grains and same has been observed in the correlation studies (Table 4). Width and thickness had a positive significant $(\mathrm{P} \leq 0.05)$ effect on geometric mean diameter 
and arithmetic mean diameter (fig. 1) and an increase in width and thickness increased the diameter. The studies on the effect of germination time on the dimensional properties of grains are scarce. However; increase in moisture has been reported to increase the dimensional properties of grains (Bai et al., 2012; Gely and Pagano, 2017).

\subsection{Surface and frictional properties}

Surface properties play an important role in drying whether sphericity and frictional properties like angle of repose affects the rate of sliding of grains on a surface. Frictional properties are important in designing hoppers and storage structures like silos. The frictional properties of grains determine the rate of flow of grains, feed rate and also help to determine the rate of emptying of storage structures (Balasubramanian and Viswanathan, 2010). Surface and frictional properties of nongerminated finger millet and malted grains has been presented in Table 3 .

Table 3. Effect of germination on surface and frictional properties of finger millet grains

\begin{tabular}{|c|c|c|c|c|}
\hline Germination Time & $\begin{array}{c}\text { Sphericity } \\
(\mathbf{\%})\end{array}$ & $\begin{array}{c}\text { Surface area } \\
\left(\mathbf{m m}^{\mathbf{2}} \mathbf{)}\right.\end{array}$ & $\begin{array}{c}\text { Sample volume } \\
\left(\mathbf{m m}^{\mathbf{3}}\right)\end{array}$ & $\begin{array}{c}\text { Angle of Repose } \\
(\boldsymbol{\theta})\end{array}$ \\
\hline Non-germinated & $93.1 \pm 0.97^{\mathrm{cd}}$ & $6.49 \pm 0.32^{\mathrm{d}}$ & $1.48 \pm 0.12^{\mathrm{c}}$ & $24.99 \pm 1.07^{\mathrm{g}}$ \\
\hline Soaked & $97.6 \pm 0.76^{\mathrm{ab}}$ & $6.65 \pm 0.99^{\mathrm{cd}}$ & $1.59 \pm 0.36^{\mathrm{bc}}$ & $24.93 \pm 0.52^{\mathrm{g}}$ \\
\hline 12 hour & $97.9 \pm 1.05^{\mathrm{a}}$ & $7.57 \pm 0.76^{\mathrm{abc}}$ & $1.93 \pm 0.28^{\mathrm{ab}}$ & $26.14 \pm 0.21^{\mathrm{f}}$ \\
\hline 24 hour & $98.7 \pm 0.58^{\mathrm{a}}$ & $7.78 \pm 0.44^{\mathrm{ab}}$ & $2.02 \pm 0.17^{\mathrm{a}}$ & $27.73 \pm 0.53^{\mathrm{e}}$ \\
\hline 36 hour & $97.3 \pm 1.31^{\mathrm{ab}}$ & $7.98 \pm 0.37^{\mathrm{ab}}$ & $2.08 \pm 0.17^{\mathrm{a}}$ & $28.64 \pm 0.25^{\mathrm{d}}$ \\
\hline 48 hour & $95.4 \pm 1.12^{\mathrm{bc}}$ & $8.09 \pm 0.60^{\mathrm{ab}}$ & $2.09 \pm 0.22^{\mathrm{a}}$ & $29.71 \pm 0.48^{\mathrm{c}}$ \\
\hline 60 hour & $92.6 \pm 3.5^{\mathrm{d}}$ & $8.30 \pm 0.71^{\mathrm{ab}}$ & $2.13 \pm 0.32^{\mathrm{a}}$ & $31.89 \pm 0.38^{\mathrm{b}}$ \\
\hline 72 hour & $86.1 \pm 0.28^{\mathrm{e}}$ & $8.35 \pm 0.01^{\mathrm{a}}$ & $2.03 \pm 0.00^{\mathrm{a}}$ & $32.81 \pm 0.48^{\mathrm{a}}$ \\
\hline 84 hour & $85.3 \pm 0.47^{\mathrm{ef}}$ & $7.58 \pm 0.04^{\mathrm{abc}}$ & $1.74 \pm 0.02^{\mathrm{abc}}$ & $29.81 \pm 0.33^{\mathrm{c}}$ \\
\hline 96 hour & $83.1 \pm 0.22^{\mathrm{f}}$ & $7.29 \pm 0.06^{\mathrm{bcd}}$ & $1.61 \pm 0.02^{\mathrm{bc}}$ & $28.52 \pm 0.29^{\mathrm{de}}$ \\
\hline
\end{tabular}

*Values are means \pm SD of 5 replications. Different superscripts in a column indicate that they are significantly $(\mathrm{P}<$ $0.05)$ different to each other determined by Duncan's tests

Sphericity, surface area and surface volume of the non-germinated finger millet grains was 93.1, $6.49 \mathrm{~mm}^{2}$ and $1.48 \mathrm{~mm}^{3}$, respectively. Bai et al. (2012) reported sphericity ranging from 0.94 to $0.99 \%$ for non-germinated finger millet grains. Ramashia et al. (2017) reported sphericity in the range of 73.75 to $92.43 \%$ for the black, creamy and brown cultivars of finger millet. With increase in germination time from 0 to 24 hours, sphericity was increased from initial $93.1 \%$ to $98.7 \%$. The increase in sphericity up to 24 hours might be due to the swelling of starch granules on soaking (Mir and
Bosco, 2013). Germination beyond 24 hours resulted in linear decrease in sphericity i.e. from $98.7 \%$ to $83.1 \%$. The reason for decrease in sphericity after 24 hours of germination might be due to more increase in length as compared to width and thickness. An increase in surface area $\left(6.49\right.$ to $\left.8.30 \mathrm{~mm}^{2}\right)$ and sample volume (1.48 to $2.13 \mathrm{~mm}^{3}$ ) was observed which might have been due to the increase in dimensional parameters like length, width and thickness (Table 2) and same has been observed in correlation studies (Table 4). 
Table 4. Correlation of the effect of germination time on various engineering parameters

\begin{tabular}{|c|c|c|c|c|c|c|c|c|c|c|c|c|c|c|}
\hline & & & & & & & & & & & & & & \\
\hline Parameters & $\begin{array}{l}\text { Malting } \\
\text { Loss } \\
(\%)\end{array}$ & $\begin{array}{c}\text { Thous } \\
\text { and } \\
\text { kerne } \\
\text { l } \\
\text { Weig } \\
\text { ht (g) }\end{array}$ & $\begin{array}{c}\text { Bulk } \\
\text { Densi } \\
\text { ty } \\
(\mathbf{K g} / \\
\left.\mathbf{m}^{3}\right)\end{array}$ & $\begin{array}{c}\text { True } \\
\text { Densi } \\
\text { ty } \\
(\mathbf{K g} / \\
\left.\mathbf{m}^{\mathbf{3}}\right)\end{array}$ & $\begin{array}{c}\text { Por } \\
\text { osit } \\
\mathbf{y} \\
(\%)\end{array}$ & $\begin{array}{c}\text { Lengt } \\
\text { h } \\
(\mathbf{m m})\end{array}$ & $\begin{array}{l}\text { Width } \\
(\mathbf{m m})\end{array}$ & $\begin{array}{l}\text { Thickn } \\
\text { ess } \\
(\mathbf{m m})\end{array}$ & $\begin{array}{c}\text { Geomet } \\
\text { ric } \\
\text { Mean } \\
\text { Diamet } \\
\text { er } \\
(\mathbf{m m})\end{array}$ & $\begin{array}{c}\text { Arithm } \\
\text { etic } \\
\text { Mean } \\
\text { Diamet } \\
\text { er } \\
(\mathbf{m m})\end{array}$ & $\begin{array}{l}\text { Spheric } \\
\text { ity }(\%)\end{array}$ & $\begin{array}{c}\text { Surface } \\
\text { Area } \\
\left(\mathbf{m m}^{2}\right)\end{array}$ & $\begin{array}{c}\text { Sample } \\
\text { Volum } \\
\text { e } \\
\left(\mathbf{m m}^{3}\right)\end{array}$ & $\begin{array}{c}\text { Angle of } \\
\text { Repose }(\theta)\end{array}$ \\
\hline Malting loss (\%) & 1 & $.997^{*}$ & $.9 \overline{7} 6^{*}$ & $.984^{*}$ & $\begin{array}{l}- \\
.64 \\
7^{*}\end{array}$ & $.922^{* *}$ & -.349 & -.472 & .043 & .131 & $-.907^{* *}$ & .398 & .047 & $.714^{*}$ \\
\hline $\begin{array}{l}\text { Thousand kernel } \\
\text { weight (g) }\end{array}$ & & 1 & $.980^{*}$ & $.983^{*}$ & $\begin{array}{l}.67 \\
6^{*}\end{array}$ & $.926^{* *}$ & .300 & .426 & -.092 & -.179 & $.882^{* *}$ & -.438 & -.096 & $-.738^{*}$ \\
\hline Bulk density $\left(\mathrm{Kg} / \mathrm{m}^{3}\right)$ & & & 1 & $.992^{*}$ & $\begin{array}{l}.70 \\
7^{*}\end{array}$ & $.887^{* *}$ & .247 & .373 & -.122 & -.208 & $.827^{* *}$ & -.448 & -.127 & $-.704^{*}$ \\
\hline True density $\left(\mathrm{Kg} / \mathrm{m}^{3}\right)$ & & & & 1 & $\begin{array}{l}.69 \\
2^{*}\end{array}$ & $.895^{* *}$ & .294 & .402 & -.086 & -.176 & $.852^{* *}$ & -.421 & -.090 & $-.689^{*}$ \\
\hline Porosity (\%) & & & & & 1 & $.815^{* *}$ & -.457 & -.328 & $-.764^{*}$ & $-.820^{* *}$ & .337 & $-.923^{* *}$ & $-.760^{*}$ & $-.879^{* *}$ \\
\hline Length (mm) & & & & & & 1 & -.060 & -.220 & .345 & .427 & $-.793^{* *}$ & $.669^{*}$ & .347 & $.900^{* *}$ \\
\hline Width (mm) & & & & & & & 1 & $.951^{* *}$ & $.910^{* *}$ & $.868^{* *}$ & $.636^{*}$ & $.701^{*}$ & $.912^{* *}$ & .314 \\
\hline Thickness (mm) & & & & & & & & 1 & $.819^{* *}$ & $.769^{* *}$ & $.767^{* *}$ & .557 & $.818^{* *}$ & .128 \\
\hline $\begin{array}{l}\text { Geometric mean } \\
\text { diameter }(\mathrm{mm})\end{array}$ & & & & & & & & & 1 & $.995^{* *}$ & .286 & $.927^{* *}$ & $.998^{* *}$ & $.639^{*}$ \\
\hline $\begin{array}{l}\text { Arithmetic Mean } \\
\text { Diameter (mm) }\end{array}$ & & & & & & & & & & 1 & .200 & $.955^{* *}$ & $.991^{* *}$ & $.690^{*}$ \\
\hline Sphericity (\%) & & & & & & & & & & & 1 & -.089 & .285 & -.500 \\
\hline Surface area $\left(\mathrm{mm}^{2}\right)$ & & & & & & & & & & & & 1 & $.929^{* *}$ & $.870^{* *}$ \\
\hline $\begin{array}{l}\text { Sample volume } \\
\left(\mathrm{mm}^{3}\right)\end{array}$ & & & & & & & & & & & & & 1 & $.653^{*}$ \\
\hline Angle of repose $(\theta)$ & & & & & & & & & & & & & & 1 \\
\hline
\end{tabular}

**. Correlation is significant at the 0.01 level (2-tailed).

*. Correlation is significant at the 0.05 level (2-tailed) 
An increase in surface area and sample volume has been also reported in maize, wheat and paddy on increase of moisture content (Adebowale et al., 2012; Bai et al., 2012; Gelly and Pagano, 2017). Soaking had a nonsignificant effect on angle of repose. However, a significant $(\mathrm{P} \leq 0.05)$ increase in angle of repose was found with increase in germination time. The reason for increase in angle of repose might be the adherence of dried epicotyl and hypocotyl to grain after drying which increased the overall friction and hence resulted in a high heap.

\subsection{Cluster analysis}

A dendrogram for different treatments (i.e. soaking time and germination time) on the engineering properties of finger millet grains is shown in Figure 2. Cluster analysis grouped the data in 2 major groups. The first group consists of soaked, 12 hour germinated grains, nongerminated grains and 24 hour germinated grains.

The second group consists of grains germinated for 36-96 hours. Group 2 was further subdivided into 2 subgroups and showed that the grains germinated for 60,72 , 36 and 48 hours were in same group and had the most similar engineering properties. While, the engineering properties of grains germinated for 84 hours and 96 hours were different from others.

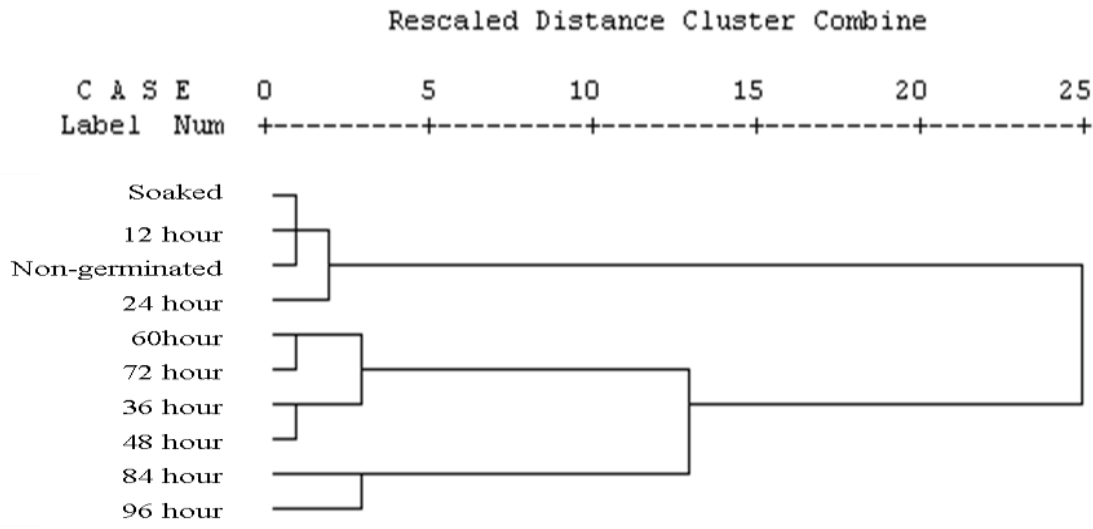

Figure 2. Dendrogram of the engineering properties of the finger millet grains as affected by the germination time

\section{Conclusions}

An increase in germination time of finger millet from 0 to 96 hours resulted in increased malting loss. Malting loss was directly proportional to thousand kernel weight, bulk density and true density and hence an increase in malting loss resulted in decreased values for these parameters. Initial germination time of 24 hours increased the dimensional and surface properties followed by a decrease on prolonged germination. Dendrogram grouped finger millet samples germinated for $0-24$ hours in a single group and hence it can be concluded that existing handling equipments and storage structures can be used for finger millet germinated up to 24 hours with minimum changes. Correlation study suggests that malting loss had a significant effect on gravimetric and dimensional properties, which in turn affect the surface properties like surface area and sphericity. The change in sphericity had a significant effect on frictional properties like angle of repose. Therefore, in the light of results it is suggested that for extended germination time beyond 24 hours the material handling equipments and storage structures should be designed accordingly.

\section{References}

Adebowale, A. A., Fetuga, G. O., Apata, C. B., Sanni, L. O. (2012). Effect of variety and initial moisture content on physical properties of improved millet grains. Nigerian Food Journal, 30(1), 5-10. 
Admassu, S., Teamir, M., Alemu, D. (2009). Chemical Composition of local and Improved finger millet [Eleusine corocana (L.) Gaetrtin] varieties grown in Ethiopia. Ethopian Journal of Health Science, 19(1), 16-23.

Association of Official Analytical Chemists. (2010). In: Official methods of analysis, the association of official analytical chemists $\left(17^{\text {th }}\right.$ ed. $)$ (ed. W. Horwitz). AOAC International, Maryland, USA.

Bai, R. S., Sharanagouda, H., Udaykumar, N. (2012). Engineering properties of finger millet (Eleusine coracana L.) grains. International Journal of Agricultural Engineering, 5(2), 178-81.

Balasubramanian, S., Viswanathan, R. (2010). Influence of moisture content on physical properties of minor millets. Journal of Food Science and Technology, 47(3), 27984.

Burton, G. W., Forston, J. C. (1966). Inheritance and utilization of five dwarfs in pearl millet (Pennisetum typhoides) breeding. Crop Science, 6(1), 69-70.

Burton, G. W., Wallace, A. T., Rachie, K. O. (1972). Chemical Composition and Nutritive Value of Pearl Millet (Pennisetum typhoides (Burm.) Stapf and EC Hubbard) Grain1. Crop Science, 12(2), 187-88.

CGIAR. (2017). The World's dry areas. Retrieved from CGIAR website: http://drylandsystems.cgiar.org/content/wor lds-dry-areas

Devi, P. B., Vijayabharathi, R., Sathyabama, S., Malleshi, N. G., Priyadarisini, V. B. (2014). Health benefits of finger millet (Eleusine coracana $\mathrm{L}$.) polyphenols and dietary fiber: a review. Journal of Food Science and Technology, 51(6), 1021-40.

Gely, M. C., Pagano, A. M. (2017). Effect of moisture content on engineering properties of sorghum grains. Agricultural Engineering International CIGR, 19(2), 200-9.

Handa, V., Kumar, V., Panghal, A., Suri, S., Kaur, J. (2017). Effect of soaking and germination on physicochemical and functional attributes of horsegram flour. Journal of Food Science and Technology, 54(13), 4229-39.

Jain, R.K., Bal, S. (1997). Properties of pearl millet. Journal of Agricultural Engineering Research, 66(2), 85-91.

Kumar, A. (2013). Refinement of the technology of the traditional sur production in Himachal Pradesh, Thesis: Masters in Food Technology; Dr. Y. S. Parmar University of Horticulture and Forestry, Nauni, Solan.

Kumar, S., Prasad, K. (2013). Effect of paddy parboiling and rice puffing on physical, optical and aerodynamic characteristics. International Journal of Agriculture and Food Science and Technology, 4(8), 765-70.

Ledbetter, C. A., \& Sisterson, M. S. (2010). Carpological variability of almond [Prunus dulcis (Mill.) DA Webb cv. Nonpareil] in a single orchard during seven consecutive harvests. HortScience, 45(12), 1788-92.

Li, C., Oh, S. G., Lee, D. H., Baik, H. W., Chung, H. J. (2017). Effect of germination on the structures and physicochemical properties of starches from brown rice, oat, sorghum, and millet. International Journal of Biological Macromolecules, 105, 931939.

Mariotti, M., Alamprese, C., Pagani, M. A., Lucisano, M. (2006). Effect of puffing on ultrastructure and physical characteristics of cereal grains and flours. Journal of Cereal Science, 43(1), 47-56.

Mbithi-Mwikya, S., Van Camp, J., Yiru, Y., Huyghebaert, A. (2000). Nutrient and antinutrient changes in finger millet (Eleusine coracan) during sprouting. LWTFood. Science and Technology, 33(1), 9-14.

Mir, S. A., Bosco, S. J. (2013). Effect of soaking temperature on physical and functional properties of parboiled rice cultivars grown in temperate region of India. Food and Nutrition Science, 4(3), 282.

Nirmala, M., Rao, M. S., Muralikrishna, G. (2000). Carbohydrates and their degrading enzymes from native and malted finger 
millet (Ragi, Eleusinen coracana, Indaf15). Food Chemistry, 69(2), 175-180.

Onyango, C. A., Ochanda, S. O., Mwasaru, M. A., Ochieng, J. K., Mathooko, F. M., Kinyuru, J. N. (2013). Effects of malting and fermentation on anti-nutrient reduction and protein digestibility of red sorghum, white sorghum and pearl millet. Journal of Food Research, 2(1), 41.

Owolarafe, O. K., Olabige, M. T., Faborode, M. O. (2007). Physical and mechanical properties of two varieties of fresh oil palm fruit. Journal of Food Engineering, 78(4), 1228-32.

Pawar, P. A., Dhanvijay, V. P. (2007). Weaning foods: An overview. Beverage Food World, 34(11), 27-33.

Ramashia, S. E., Gwata, E. T., MeddowsTaylor, S., Anyasi, T. A., Jideani, A. I. O. (2017). Some physical and functional properties of finger millet (Eleusine coracana) obtained in sub-Saharan Africa. Food Research International, 27.

Saleh, A.S., Zhang, Q., Chen, J., Shen, Q. (2013). Millet grains: nutritional quality, processing, and potential health benefits. Comprehensive Reviewes in Food. Science and Food Safety, 12(3), 281-295.

Sharma, S.K., Dubey, R. K., Teckchandani, C. K. (1985). Engineering properties of black gram, soybean and green gram. Proceedings of Indian Society of Agriculture Engineering, 3, 181-85.

Shukla, K., Srivastava, S. (2014). Evaluation of finger millet incorporated noodles for nutritive value and glycemic index. Journal of Food Science and Technology, 51(3), 527-34.

Singh, P., Raghuvanshi, R. S. (2012). Finger millet for food and nutritional security. African Journal of Food Science, 6(4), 77-84.

Singh, P., Srivastava, S. (2006). Nutrient Composition of Some New Varieties of Finger Millet (Eleusine coracana). Journal of Community Mobilization and Sustainable Development, 1, 115-20.

Sobukola, O. P., Kajihausa, O. E., Onwuka, V. I., Esan, T. A. (2013). Physical properties of high quality maize (Swam 1 variety) seeds (Zea mays) as affected by moisture levels. African Journal of Food Science, 7(1), 1-8.

Sreenarayanan, V. V., Subramanian, V., \& Visvanathan, R. (1985). Physical and thermal properties of soybean. Proceedings of Indian Society of Agriculture Engineering, 3, 161-169.

Tatala, S., Ndossi, G., Ash, D., Mamiro, P. (2007). Effect of germination of finger millet on nutritional value of foods and effect of food supplement on nutrition and anaemia status in Tanzania children. Tanzanian Journal of Health Research, 9(2), 77-86.

Upadhyaya, H. D., Ramesh, S., Shivali, S., Singh, S. K., Varshney, S. K., Sarma, N. D., Ravishankar, C.R., Narasimhudu, Y., Reddy, V.G., Sahrawat, K.L., Dhanalakshmi, T.N. (2011). Genetic diversity for grain nutrients contents in a core collection of finger millet (Eleusine coracana (L.) Gaertn.) germplasm. Field Crops Research, 121(1), 42-52.

Venkateswaran, V., \& Vijayalakshmi, G. (2010). Finger millet (Eleusine coracana) - an economically viable source for antihypercholesterolemic metabolites production by Monascuspurpureus. Journal of Food Science and Technology, 47(4), 426-31.

Verma, V., Patel, S. (2013). Value added products from nutri-cereals: Finger millet (Eleusine coracana). Emirates Journal of Food and Agriculture, 25(3), 169.

Vidal-Valverde, C., Frias, J., Sierra, I., Blazquez, I., Lambein, F., Kuo, Y. H. (2002). New functional legume foods by germination: effect on the nutritive value of beans, lentils and peas. European Food Research and Technology, 215(6), 472-77.

\section{Acknowledgements}

Authors are thankful to Asia Pacific Association of Agricultural Research Institutions, Bangkok, Thailand for providing research funding under CRP DC Dryland Cereals Scholarship Program. 